\title{
Levels, Potential Sources and Risk Assessment of Organochlorine Pesticides in Atmospheric Particulate Matter at Regional Background Site
}

\author{
Juan Liu ${ }^{1,2}$, Hui-Yu Wang ${ }^{1,2}$, Shan-Jun Song ${ }^{3}$, Hui-Chun Ma ${ }^{4}$, Wen-Tao Sun ${ }^{1}$, Lei Wang ${ }^{4 * *}$, \\ Yan Wang ${ }^{5}$, Xian-Liang $\mathrm{Yi}^{6}$, Li-Qiong Guo ${ }^{7}$, Peng-Hui $\mathrm{Li}^{1,2,8^{*}}$ \\ ${ }^{I}$ School of Environmental Science and Safety Engineering, Tianjin University of Technology, Tianjin 300384, China \\ ${ }^{2}$ Tianjin Key Laboratory of Hazardous Waste Safety Disposal and Recycling Technology, Tianjin 300384, China \\ ${ }^{3}$ National Institute of Metrology, Beijing 100029, China \\ ${ }^{4}$ Hebei research center for Geoanalysis, Hebei 071000, China \\ ${ }^{5}$ School of Environmental Science and Engineering, Shandong University, Qingdao 266237, China \\ ${ }^{6}$ School of Food and Environment, Dalian University of Technology, Panjin 124221, China \\ ${ }^{7}$ Department of Occupational and Environmental Health, School of Public Health, Tianjin Medical University, Tianjin \\ 300070, China \\ ${ }^{8}$ Tianjin SF-Bio Industrial Bio-Tec Co., Ltd, Tianjin 300462, China
}

\begin{abstract}
Forty-eight $\mathrm{PM}_{2.5}$ samples were collected from June to August 2015 at the summit of Mount Tai. The samples were analyzed to determine the concentrations, potential sources and health risk of organochlorine pesticides (OCPs). Total OCPs concentration in $\mathrm{PM}_{2.5}$ ranged from 20.5 to $331 \mathrm{pg} \mathrm{m}^{-3}$. Hexachlorocyclohexane (HCHs) were the most abundant compounds. The sources of OCPs used potential source contribution function (PSCF), back trajectory analysis and principal component analysis suggested that the southwest agricultural areas and southeast regions of Mount Tai were the significant contributions regions of OCPs. Both old residual and new input were considered to the contribution of OCPs contamination. Human health risk assessment was carried out by non-carcinogenic health hazard quotient (HQ). The HQ values through inhalation and dermal contact ranged from $9.28 \times 10^{-12}$ to $6.56 \times 10^{-3}$, indicating a negligible risk of the study area.
\end{abstract}

Keywords: $\mathrm{PM}_{2.5}$; Organochlorine pesticides (OCPs); Concentration; Long-range transport; Health risk.

\section{INTRODUCTION}

Organochlorine pesticides (OCPs), a group of persistent organic pollutants (POPs), were extensively used in agriculture from the 1950s to 1970 s all over the world due to their low cost and the effective performance in controlling insects (Jin et al., 2013). However, due to their high toxicity, carcinogenic property and resistance to degradation, OCPs are of special concern in previous studies (Bräuner et al., 2011; Jiao et al., 2018). The application of OCPs have been restricted in most of the developed and developing countries since 1980s. However, they were still widely detected in different regions because of the previous residues

\footnotetext{
* Corresponding author.

Tel.: 862260214203

E-mail address: lipenghui406@163.com

${ }^{* *}$ Corresponding author.

E-mail address: wanglei8812@126.com
}

(Bozlaker et al., 2009; Zhou et al., 2019). In atmosphere, OCPs mainly came from agricultural soil suspension and synthesis of chlorinated product (Chakraborty et al., 2013), and can be transported over long distances from their sources and had been found in remote locations where they have never been used or produced (Kirchner et al., 2016).

China was a major producer and consumer of OCPs in the world. Before they were prohibited in 1983, the total production of hexachlorocyclohexane (HCHs) and dichlorodiphenyltrichloroethane (DDT) in China was about 4.9 and 0.4 million tons, accounting for $33 \%$ and $20 \%$ of the total world production, respectively (Xu et al., 2011). Studies concerning OCPs compounds in atmospheric environment have been performed in different regions of China (Han et al., 2016; Wang et al., 2008). In Beijing, the levels were found to be $212 \mathrm{pg} \mathrm{m}^{-3}$ for $\mathrm{HCHs}$ and $522 \mathrm{pg} \mathrm{m}^{-3}$ for DDTs in 2005, and their concentrations were decreased to $101 \mathrm{pg} \mathrm{m}^{-3}$ and $146 \mathrm{pg} \mathrm{m}^{-3}$, respectively in 2009 (Zhang et al., 2011). However, through the global distillation and grasshopper effect, OCPs were detected in many background sites such as Antarctica (Dickhut et al., 2005), and the 
Arctic (Becker et al., 2012) where had never used OCPs. Understand the long-range transport of OCPs in atmosphere can give important information for the global-scale existence and fates of these pollutants. In the present study, fine particle $\left(\mathrm{PM}_{2.5}\right)$ samples were collected at the summit of Mount Tai, which serves as a regionally background site and a unique environment to investigate the long-range transport of pollutants in troposphere (Liu et al., 2017). OCP compounds were analyzed in collected $\mathrm{PM}_{2.5}$ samples, and the objectives of the present study were to (1) survey the regional pollution levels of OCPs in $\mathrm{PM}_{2.5}$, (2) identify possible sources and long-range transport of OCPs from contaminated regions, and (3) provide comprehensive fundamental data for risk assessment of OCPs in atmospheric environment.

\section{EXPERIMENT AND METHOD}

\section{Sampling}

The sampling was carried out in the meteorological monitoring station on Mount Tai $\left(117^{\circ} 06^{\prime} \mathrm{E}, 36^{\circ} 16^{\prime} \mathrm{N}\right.$, $1532.7 \mathrm{~m}$ A.S.L), located in free troposphere, is one of the highest peaks in northern China. A total of $48 \mathrm{PM}_{2.5}$ samples were collected from June 15 to August 11, 2015, using a high-volume air sampler (HI-Q 7386, Inc. San Diego, manufactured by Environmental Products Company, CA, USA) at a flow rate of $1000 \mathrm{~L} \mathrm{~min}^{-1}$ with 24 -h sampling intervals. Before sampling, the quartz fiber filter (QFF; $203 \times 254 \mathrm{~mm}$, Munktell, Sweden) was heated at $600^{\circ} \mathrm{C}$ for $2 \mathrm{~h}$ to eliminate organic substances, and equilibrated at controlled environment condition (relative humidity of $35 \% \pm$ $1 \%$ and temperature of $22 \pm 2^{\circ} \mathrm{C}$ ) for $48 \mathrm{~h}$ (U.S. EPA, 2001). Then they were weighed using a microbalance (balance sensitivity $\pm 0.001 \mathrm{mg}$, Mettler Toledo XP6). After sampling, the quartz filters were wrapped by aluminum foil, packaged in polyethylene bags, transported to laboratory as soon as possible. After weighed in controlled conditions described above, samples were stored at $-20^{\circ} \mathrm{C}$ until analysis.

\section{Sample Analysis}

Filters were extracted by accelerated solvent extraction (ASE 300, Dionex, Sunnyvale, US). The extraction procedures were repeated twice, which was operated with a mixture solvent of $n$-hexane/acetone $(1: 1, \mathrm{v} / \mathrm{v})$ at $100^{\circ} \mathrm{C}$ and $1500 \mathrm{psi}$. The extract was concentrated by a rotary evaporator and then reduced to $1 \mathrm{~mL}$ under a gentle stream of nitrogen, transferred into a glass vial for analysis.

The OCPs were analyzed using a gas chromatographymass spectrometer (GC-MS) (7890B-5977A, Agilent Technologies, USA) equipped with a fused silica capillary DB-5MS column $(30 \mathrm{~m} \times 0.25 \mathrm{~mm} \times 0.25 \mu \mathrm{m})$ using selective ion monitoring mode. The inlet, transfer line, and ion source temperature were $250^{\circ} \mathrm{C}, 260^{\circ} \mathrm{C}$, and $230^{\circ} \mathrm{C}$, respectively. $2 \mu \mathrm{L}$ of each sample was injected in the splitless mode.

\section{Quality Assurance and Quality Control (QA/QC)}

Strict QA/QC procedures were performed during analysis processes. Laboratory and field blanks were prepared and analyzed in the same manner as samples, and OCPs were not detected in these blanks. The method detection limit (MDL) were as follows: $1 \mathrm{pg} \mathrm{m}^{-3}$ for Hexachlorobenzene (HCB) and $\alpha-\mathrm{HCH} ; 1.5 \mathrm{pg} \mathrm{m}^{-3}$ for $\beta-\mathrm{HCH}, \gamma-\mathrm{HCH}$ and $\delta-\mathrm{HCH}$; $2.0 \mathrm{pg} \mathrm{m}^{-3}$ for heptachlor, heptachlor epoxide and aldrin; $25 \mathrm{pg} \mathrm{m}^{-3}$ for $\mathrm{p}, \mathrm{p}$-DDT and mirex. Concentrations below the method detection limit were regarded as the lowest values. Samples were analyzed in triplicate with relative standard deviations (RSDs) less than 13\%. The recoveries were $61 \% \pm 23 \%$ in the $\mathrm{PM}_{2.5}$ samples.

\section{RESULTS AND DISCUSSION}

\section{OCPs Concentration}

Ten OCPs $(\alpha-H C H, \beta-H C H, \gamma-H C H, \delta$-HCH, p,p'-DDT, $\mathrm{HCB}$, heptachlor, heptachlor epoxide, mirex and aldrin) were detected in this present study (Table 1). The concentration of $\Sigma$ OCPs in $\mathrm{PM}_{2.5}$ ranged from 20.5 to $331 \mathrm{pg} \mathrm{m}^{-3}$, with an average of $60.3 \pm 53.3 \mathrm{pg} \mathrm{m}^{-3}$.

$\mathrm{HCHs}$ used to be a dominant commercial insecticide. In this study, HCHs $(\Sigma \mathrm{HCH}$, sum of $\alpha-\mathrm{HCH}, \beta-\mathrm{HCH}, \gamma-\mathrm{HCH}$, and $\delta-\mathrm{HCH}$ ) exhibited the highest concentration, with an average of $29.0 \pm 28.1 \mathrm{pg} \mathrm{m}^{-3}$. The concentrations were comparable to those observed in air samples from background sites such as the Atlantic Ocean $\left(3 \mathrm{pg} \mathrm{m}^{-3}\right.$ for $\alpha-\mathrm{HCH}$ and $22 \mathrm{pg} \mathrm{m}^{-3}$ for $\gamma-\mathrm{HCH}$ ) (Jaward et al., 2004) and Singapore $\left(1.38 \pm 0.86 \mathrm{pg} \mathrm{m}^{-3}\right.$ for $\alpha-\mathrm{HCH}$, and $1.36 \pm 1.84 \mathrm{pg} \mathrm{m}^{-3}$ for

Table 1. OCPs concentrations $\left(\mathrm{pg} \mathrm{m}^{-3}\right)$ in atmospheric particles of Mount Tai from June 2015 to August 2015.

\begin{tabular}{llll}
\hline Compounds & Mean $\left(\mathrm{pg} \mathrm{m}^{-3}\right)$ & Range $\left(\mathrm{pg} \mathrm{m}^{-3}\right)$ & FD $\%$ \\
\hline$\alpha-\mathrm{HCH}$ & $1.46 \pm 3.15$ & $\mathrm{ND}-22.0$ & 27 \\
$\beta$-HCH & $10.3 \pm 14.7$ & $\mathrm{ND}-85.3$ & 43 \\
$\gamma$-HCH & $5.91 \pm 5.41$ & $\mathrm{ND}-26.4$ & 75 \\
$\delta$-HCH & $11.3 \pm 8.34$ & $\mathrm{ND}-37.2$ & 46 \\
p,p'-DDT & $5.80 \pm 12.1$ & $\mathrm{ND}-61.3$ & 40 \\
HCB & $3.65 \pm 3.49$ & $\mathrm{ND}-14.8$ & 78 \\
Heptachlor & $3.72 \pm 4.90$ & $\mathrm{ND}-30.3$ & 65 \\
Heptachlor epoxide & $3.50 \pm 2.88$ & $\mathrm{ND}-14.6$ & 41 \\
Mirex & $10.1 \pm 10.9$ & $\mathrm{ND}-49.3$ & 84 \\
Aldrin & $4.48 \pm 5.46$ & $\mathrm{ND}-34.4$ & 75 \\
$\Sigma$ HCH & $29.0 \pm 28.1$ & $8.79-108$ & \\
$\Sigma$ OCP & $60.3 \pm 53.3$ & $20.5-331$ & \\
\hline
\end{tabular}


$\gamma$-HCH) (He et al., 2009) (Table 2). They were lower than some regions, such as the South China Sea $\left(67 \pm 33 \mathrm{pg} \mathrm{m}^{-3}\right.$ for $\alpha-\mathrm{HCH}$, and $771 \pm 310 \mathrm{pg} \mathrm{m}^{-3}$ for $\gamma-\mathrm{HCH}$ ) (Lin et al., 2012; Zhang et al., 2007), Taihu Lake (74 $\pm 45 \mathrm{pg} \mathrm{m}^{-3}$ for $\alpha-\mathrm{HCH}$, and $46 \pm 24 \mathrm{pg} \mathrm{m}^{-3}$ for $\gamma-\mathrm{HCH}$ ) (Qiu et al., 2004), and Korea background sites (71.3 $\mathrm{pg} \mathrm{m}^{-3}$ for HCHs) (Jin et al., 2013).

The concentrations of p,p'-DDT (average: $5.80 \pm 12.1$ $\mathrm{pg} \mathrm{m}^{-3}$ ) in this study were comparable to those in the China marginal seas $\left(5.1 \pm 5.1 \mathrm{pg} \mathrm{m}^{-3}\right.$ for p,p'-DDT ) (Lin et al., 2012), Korea background sites (3.5 $\mathrm{pg} \mathrm{m}^{-3}$ for DDTs) (Jin et al., 2013) and the Indian Ocean (5.9 $\mathrm{pg} \mathrm{m}^{-3}$ for p,p'-DDT) (Wurl et al., 2006). But they were significantly lower than results analyzed in particle samples in Beijing, China (273 $\pm 695 \mathrm{pg} \mathrm{m}^{-3}$ ) (Wang et al., 2008), remote area of Turkey (74 $\pm 163 \mathrm{pg} \mathrm{m}^{-3}$ ) (Ozcan and Aydin, 2010), Durban, South Africa $\left(15.0 \pm 11.7 \mathrm{pg} \mathrm{m}^{-3}\right)$ (Batterman et al., 2008), and gas samples in Tai Lake (124 $\pm 91 \mathrm{pg} \mathrm{m}^{-3}$ for $\mathrm{p}, \mathrm{p}$-DDT) (Qiu et al., 2004) and the South China Sea (58 $\pm 65 \mathrm{pg} \mathrm{m}^{-3}$ for p,p'-DDT) (Zhang et al., 2007)).

HCB was mainly used for producing pentachlorophenol sodium, wood preservation and pesticide for schistosome (Wang et al., 2008). In this study, the average concentration of HCBs $\left(3.65 \pm 3.49 \mathrm{pg} \mathrm{m}^{-3}\right)$ were comparable to those measured at the points in Durban, South Africa (4.7 \pm $2.7 \mathrm{pg} \mathrm{m}^{-3}$ ) (Batterman et al., 2008), but much lower than those observed over Korea background sites (15-256 $\mathrm{pg} \mathrm{m}^{-3}$ ) (Jin et al., 2013) and Beijing (53.7 $\left.\pm 28.1 \mathrm{pg} \mathrm{m}^{-3}\right)$ (Wang et al., 2008).

Heptachlor is an organochlorine cyclodiene insecticide isolated from technical chlordane in 1946. It was used primarily in termite, ant and soil insect control in seed grains and on crops, as well as in the home (Wang et al., 2008). It was banned in Japan since 1970s, and had not been registered for use in Mongolia, Russia and China (excluding Taiwan, which banned in 1989) (UNEP, 2003). In this study, the concentration of heptachlor ranged from $\mathrm{ND}$ to $30.3 \mathrm{pg} \mathrm{m}^{-3}$ (average $3.72 \pm 4.90 \mathrm{pg} \mathrm{m}^{-3}$ ) were comparable to the results detected in remote area, Turkey $(3 \pm$ $9 \mathrm{pg} \mathrm{m}^{-3}$ ) (Ozcan and Aydin, 2010); higher than Korea background sites (0.41 pg m ${ }^{-3}$ ) (Jin et al., 2013); but significantly lower than those regions, such as Beijing $\left(99.9 \pm 190 \mathrm{pg} \mathrm{m}^{-3}\right)$ (Wang et al., 2008).

Heptachlor epoxide was found in $41 \%$ samples in this study, ranged from ND-14.6 $\mathrm{pg} \mathrm{m}^{-3}$ and averaged $3.50 \pm$ $2.88 \mathrm{pg} \mathrm{m}^{-3}$. This non-systemic stomach and contact insecticide was used primarily against soil insects and termites, as well as cotton insects, grasshoppers, some crop pests and mosquitoes (Batterman et al., 2008). Karlsson et al. (2000) reported heptachlor epoxide levels of $0.82 \pm$ $1.9 \mathrm{pg} \mathrm{m}^{-3}$ at Lake Malawi, and Batterman et al. (2008) reported the average concentration lower than the detection limit in Durban, South Africa, which were slightly lower than our measurements.

It was worth noticing that aldrin had never been used in large amounts in China, but it was detected in most of samples on Mount Tai (range: ND-34.4 $\mathrm{pg} \mathrm{m}^{-3}$, average $4.48 \pm 5.46 \mathrm{pg} \mathrm{m}^{-3}$ ). This concentration was higher than that in Korea background sites (ND-0.65 $\mathrm{pg} \mathrm{m}^{-3}, 0.08 \mathrm{pg} \mathrm{m}^{-3}$ )
(Jin et al., 2013), but significantly lower than those in Beijing (376 $\pm 542 \mathrm{pg} \mathrm{m}^{-3}$ ) (Wang et al., 2008). Aldrin was also detected in sediments and surface water from Guanting Reservoir and in most samples of water from Qiantang River (Zhou et al., 2006). Due to its persistence and semi-volatility, aldrin can enter atmosphere by volatilization from sediments and surface water, resulting in a large-scale pollution through "the Grasshopper Effect" or long-range transport (Wang et al., 2008; Wania et al., 2010).

Mirex is a stomach insecticide that has been used to control fire ants in the southeastern US, leaf cutters in South America, harvester termites in South Africa, western harvester ants in the US and mealybugs in Hawaii. It also has been used as a fire retardant in plastics, rubber, paint, paper and electrical products (Batterman et al., 2008). It has not been produced or used in Korea, Mongolia, Russia and Japan, but it was detected in some of these areas such as the study on Korea background sites (Jin et al., 2013). In China, it was used as termiticide in some regions (UNEP, 2003). The levels of mirex in this study ranged from ND to $49.3 \mathrm{pg} \mathrm{m}^{-3}$, with an average of $10.1 \pm 10.9 \mathrm{pg} \mathrm{m}^{-3}$. The concentration was higher than that in Korea background sites (range: ND-0.78 $\mathrm{pg} \mathrm{m}^{-3}$, average: $0.04 \mathrm{pg} \mathrm{m}^{-3}$ ) (Jin et al., 2013).

\section{Source Identification of OCPs}

The concentrations and ratios of some marker OCP compounds can give the indication of the impact from different emission sources. For example, technical $\mathrm{HCH}$ and lindane was considered to be the major contribution of $\mathrm{HCH}$ in environment. Technical $\mathrm{HCH}$ consisted of $\alpha-\mathrm{HCH}$ $(55 \%-80 \%), \beta-\mathrm{HCH}(5 \%-14 \%), \gamma-\mathrm{HCH}(8 \%-15 \%)$ and $\delta$-HCH $(2 \%-16 \%)$, while lindane was made up of more than $95 \% \gamma$-HCH (Rodríguez-Garrido et al., 2010). The sources of $\mathrm{HCHs}$ can be estimated by the ratio of $\alpha-\mathrm{HCH} / \gamma-\mathrm{HCH}$. If this ratio is lower than 3 , $\mathrm{HCHs}$ was from the recent use of lindane. If the ratio is between 3 and 7 , the source of $\mathrm{HCH}$ comes from fresh input of technical $\mathrm{HCH}$. The ratio higher than 7 represents history use of technical $\mathrm{HCH}$ (Ozcan and Aydin, 2010). In the present study, the ratio of $\alpha-\mathrm{HCH} / \gamma-\mathrm{HCH}$ is between 0.03 and 1.62 , indicating $\mathrm{HCHs}$ was from recent use of lindane after technical $\mathrm{HCH}$ was banned (Huang et al., 2014; Ji et al., 2015).

To further explore the potential sources of OCPs components, principal component analysis (PCA) was applied by using SPSS version 21. The principle of PCA was to describe the covariance relationship of several variances based on some common components, which was expected to explain most of the variance in analysis results. (Cheng et al., 2017). During the analysis, several factors can be subsequently divided by a certain factor interrelation, and the higher loading in factor represented more contribution to specific variation in data. In this present study, factor loadings higher than 0.6 was supposed to they can be suitable to identify source categories, and the score plot of eigenvalues $>1$ were considered to be able to explain the variance in output data (Ji et al., 2015; Widiana et al., 2017). Finally, the emission source represented by a component 


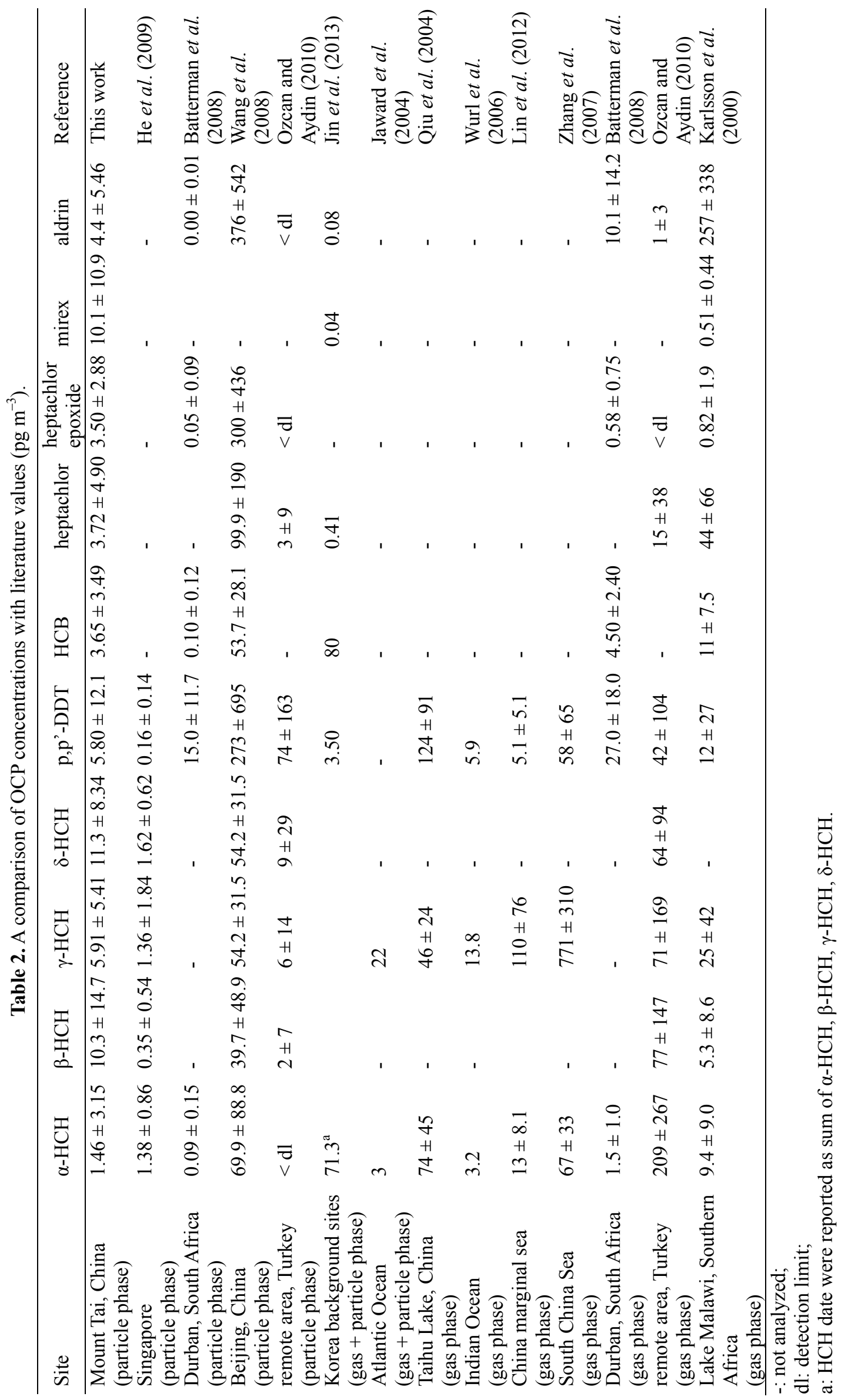


could be determined by the source profiles of pollutants contained in this component (Papaoikonomou et al., 2018). As is shown in Fig. 1, two factors accounted for $69.7 \%$ of the total data factors. The first principal component (PC1) explained $39.0 \%$ of total variance, showing high loading for p,p'-DDT, $\alpha-\mathrm{HCH}, \beta-\mathrm{HCH}$, mirex and heptachlor. p,p'-DDT was banned as a pesticide in China in 1983. $\alpha-\mathrm{HCH}$ and $\beta-\mathrm{HCH}$ were the main components of technical $\mathrm{HCHs}$, which was identified as the residues of old use $(\alpha-\mathrm{HCH} / \gamma-$ $\mathrm{HCH}$ ratio lower than 3 ). Heptachlor was the matrix of heptachlor epoxide, can be identified as previous usage before heptachlor. Thus, PC1 is assumed to be relatively old use of pesticides. The second principal component (PC2) with $30.7 \%$ of the variability occurred the high loading on $\gamma-\mathrm{HCH}, \delta-\mathrm{HCH}, \mathrm{HCB}$ and heptachlor epoxide. The presence of $\gamma-\mathrm{HCH}$ could point to the contribution of lindane of recently use. HCB was widely used fungicides in China and emitted as byproduct from chlorinated industry, such as polyvinyl chloride plastics, synthetic rubber, metal production, dye and various combustion processes (Huang et al., 2014). Heptachlor epoxide was derived by heptachlor in environment. Thus, PC2 could reflect the presence of OCPs from recently use.

\section{Long-range Atmospheric Transport}

To identify the transport patterns of OCPs and the influence of air mass transport on individual component, 24-hour air parcel back trajectories and potential source contribution function (PSCF) analysis were conducted by the Hybrid-Single Particle Integrated Trajectories (HYSPLIT 4.8) and TrajStat, respectively. The back trajectories were clustered by cluster algorithm using HYSPLIT service (Yeh et al., 2017). The PSCF analysis, combined with back trajectory results, was employed to identify the regional sources of organochlorine components. The study area was divided into some grid cells with equal size $(i \times j)$, and the PSCF value in cell $(i, j)$ was calculated by $\mathrm{m}_{\mathrm{ij}} / \mathrm{n}_{\mathrm{ij}}$ multiple $\mathrm{W}_{\mathrm{ij}}$. Where $\mathrm{m}_{\mathrm{ij}}$ and $\mathrm{n}_{\mathrm{ij}}$ represented the number of concentration points loading in cell $(i, j)$ and exceeding the threshold value in this cell, respectively. $W_{i j}$ was an empirical weight function to reduce the uncertainty of results. In the present study, the grid cells with high values exceeding 0.9 were selected as potential regional sources (Li et al., 2018; Tong et al., 2018).

As shown in Figs. 2 and 3, all the air mass back trajectories classified into four types by source direction, namely, SE-air masses, SW-air masses, NW-air masses and NE-air masses, respectively (represented the air from southeast, southwest, northwest and northeast of Mount Tai). The SE-air masses represented travelled across Jiangsu and the Yellow Sea. The SW-air masses mainly from Henan and the western of Shandong province. The $\mathrm{NW}$-air masses that most originated from continental areas in northern China crossed Inner Mongolia, Shanxi and Hebei province and reached the station. The NE-air masses were from Bohai strait and northeast of Shandong.

The largest proportion belonged to SE-air masses (31.3\%), with the highest OCPs concentration (average $95.3 \mathrm{pg} \mathrm{m}^{-3}$ ),

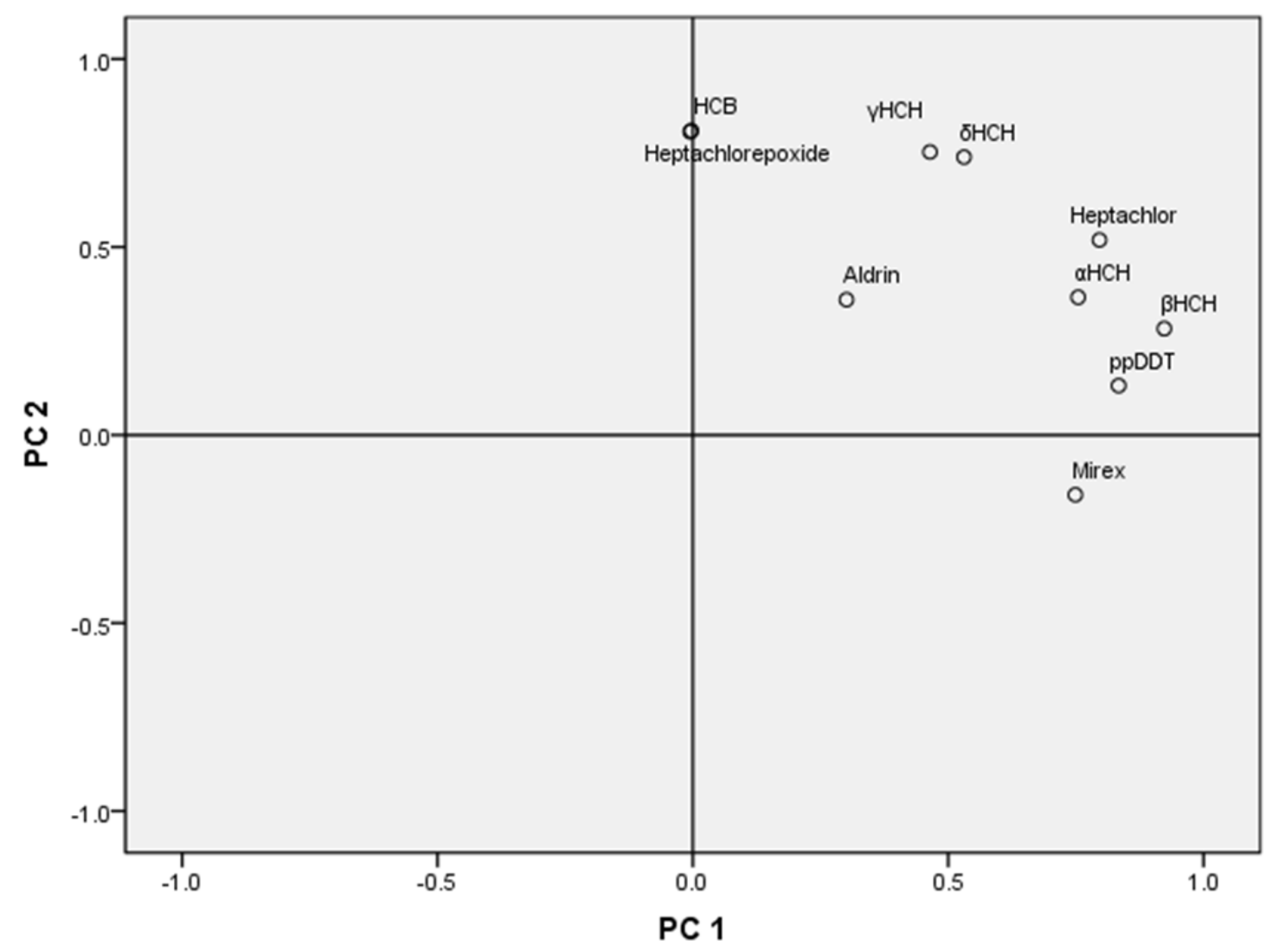

Fig. 1. Principal component analysis for OCPs. 


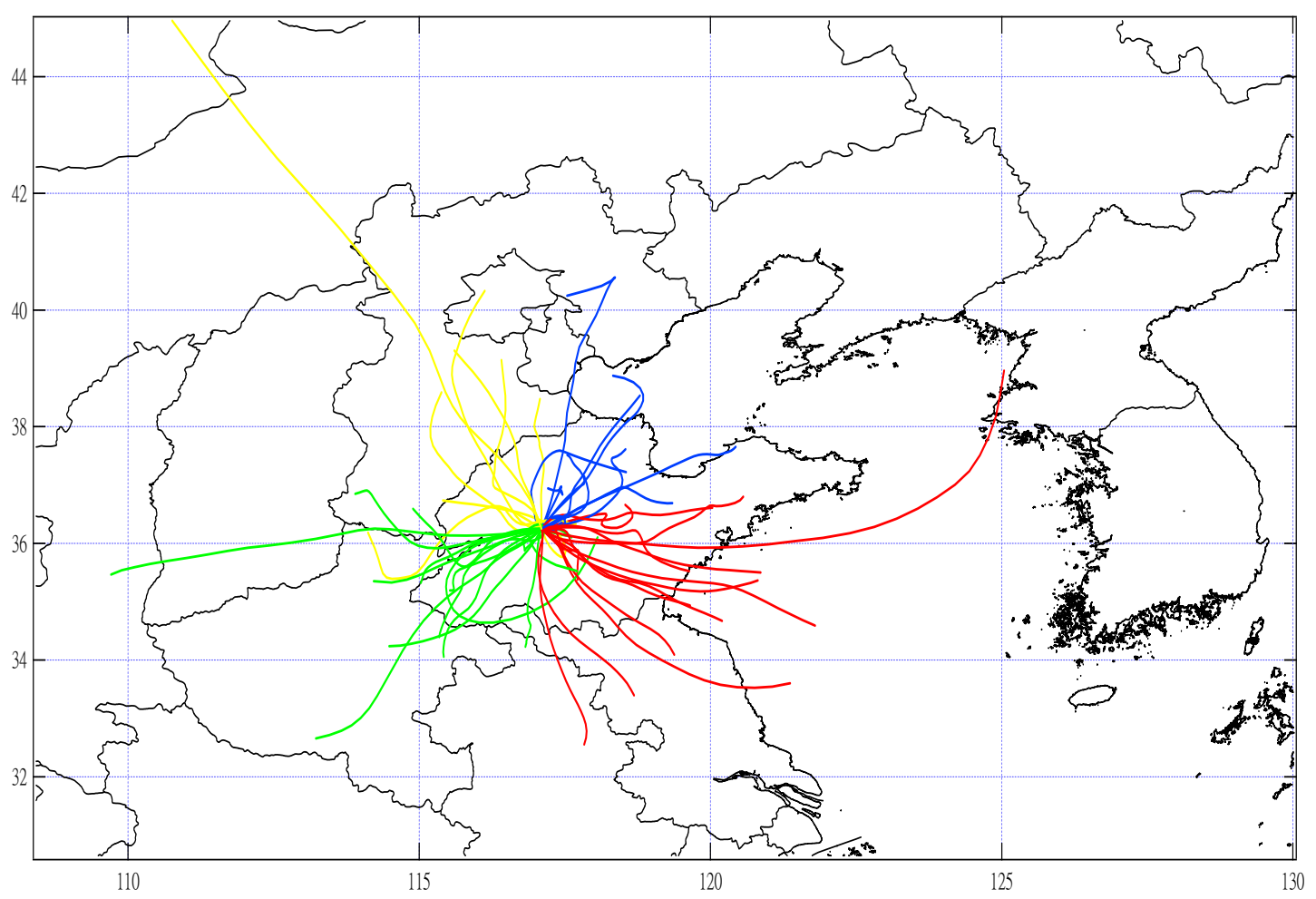

Fig. 2. 24-h back trajectories of air masses during sampling period.
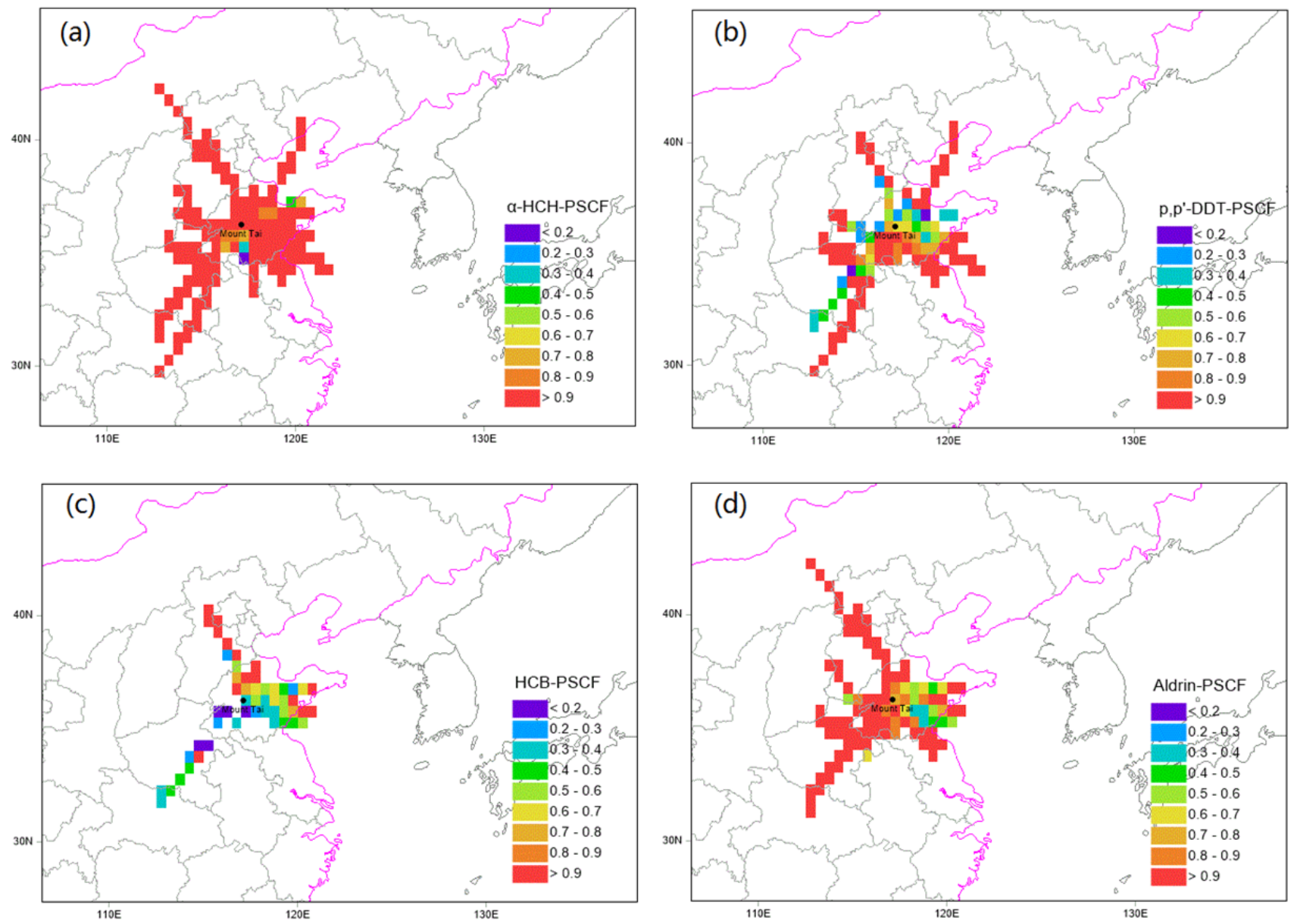

Fig. 3. Regional sources analysis of (a) $\alpha-H C H$, (b) p,p'-DDT, (c) HCB and (d) Aldrin using PSCF. 
indicating that air masses from eastern coastal area was an important potential source region of OCPs on Mount Tai, which was coincident with the previous researches (Niu et al., 2014; Ji et al., 2015). OCPs applied as pesticides still have an impact on environment, and high concentrations for DDTs, HCHs, heptachlor had been reported in this region (Zhou et al., 2013; Wang et al., 2016; Sun et al., 2017).

$\mathrm{NW}$-air masses and NE-air masses accounted for $18.8 \%$ and $20.3 \%$ of air masses, and average OCPs concentrations were $54.1 \mathrm{pg} \mathrm{m}^{-3}$ and $36.2 \mathrm{pg} \mathrm{m}^{-3}$, respectively. Some important OCP compounds had been influenced by NWair masses and NE-air masses. $\alpha-\mathrm{HCH}, \mathrm{p}, \mathrm{p}$-DDT, HCB and aldrin were associated with the air from the northwest of Mount Tai, which was consistent with the results from previous studies (Lammel et al., 2007; Liu, 2014). Agricultural activities in these regions can still consume a lot of pesticides in past decades, and make contribution of OCPs in the environment (Niu et al., 2014).

\section{Toxicity Assessment}

For atmospheric particles, exposure through inhalation and dermal contact could lead to adverse health effects. Health risk assessments for both inhalational and dermal exposures of OCPs were calculated in this study. The model was based on the Risk Assessment Guidance for Superfund, Vol. I: Human Health Evaluation Manual (U.S. EPA, 1989). Following two equations were used average daily dose (ADD) $\left(\mathrm{mg} \mathrm{kg}^{-1}\right.$ day $\left.^{-1}\right)$ to estimate human health risks associated with inhalation (ADDinh) and dermal contact (ADDdern) (Wang et al., 2018).

$$
\begin{aligned}
& A D D_{\text {inh }}=C \times \frac{I n h R \times E F \times E D}{P E F \times B W \times A T} \\
& A D D_{\text {derm }}=C \times \frac{S A \times A F \times A B S \times E F \times E D}{B W \times A T}
\end{aligned}
$$

where $\mathrm{C}$ is the concentration of OCPs $\left(\mathrm{mg} \mathrm{kg}^{-1}\right)$. InhR is the inhalation rate $\left(\mathrm{m}^{3} \mathrm{day}^{-1}\right)$. PEF is representative of the particle emission factor $\left(\mathrm{m}^{3} \mathrm{~kg}^{-1}\right)$. EF is the exposure frequency (days year ${ }^{-1}$ ). ED represents the exposure duration (years). BW is the body weight $(\mathrm{kg})$. AT is the averaging time (days). SA is the dermal exposure area $\left(\mathrm{cm}^{2}\right) . \mathrm{AF}$ is the dermal adherence factor $\left(\mathrm{mg} \mathrm{cm}{ }^{-2}\right.$ day $\left.^{-1}\right)$. ABS is the dermal adsorption fraction. These values of parameters were referenced from the literature, showing in Table 3.

After the ADD was calculated, health hazard quotient (HQ) based on non-cancer toxic risk on humans can then be estimated by dividing the average daily dose to a specific reference dose (RfD).

$$
H Q=\frac{A D D}{R f D}
$$

The reference dose (RfD) $\left(\mathrm{mg} \mathrm{kg}^{-1} \mathrm{day}^{-1}\right)$ values of $\alpha-\mathrm{HCH}, \beta-\mathrm{HCH}, \gamma-\mathrm{HCH}, \mathrm{p}, \mathrm{p}$-DDT, heptachlor, aldrin and heptachlor epoxide is $0.8,0.8,0.3,0.5,0.5,0.03$ and $1.3 \times$ $10^{-2}$, respectively (Witczak and Abdelgawad, 2014). RfD is an estimation of maximum permissible risk on human populations through daily exposure. The threshold of RfD value can be used to indicate whether there is adverse health effect during a lifetime. HQ $>1$ indicated likely adverse health effects, whereas HQ $\leq 1$ indicated unlikely adverse health effects (Witczak and Abdelgawad, 2014). The estimated HQ values of OCPs detected at Mount Tai were much lower than the acceptable level $(\mathrm{HQ} \leq 1)$ (Table 4$)$, indicating exposure to $\mathrm{PM}_{2.5}$-bound OCPs lead to an acceptable health effects in this region. However, the health effect of PM-bound OCPs had been highlighted in some regions in Northern China (Ding et al., 2015), much research work should be conducted in the future.

\section{CONCLUSIONS}

Despite most OCPs have been restricted in China, many OCP compounds are still detected in $\mathrm{PM}_{2.5}$ at Mount Tai, a regional background site in Northern China owing to their persistence and transport in the environment. The concentration of total OCPs on Mount Tai ranged from $20.5 \mathrm{pg} \mathrm{m}^{-3}$ to $331 \mathrm{pg} \mathrm{m}^{-3}$. HCHs were the most abundant OCP compounds, with an average concentration of $29.0 \mathrm{pg} \mathrm{m}^{-3}$. The results of PCA, back trajectory and PSCF analysis signaled the dominant source of OCPs were from the southwest agricultural areas and southeast regions of Mount Tai. The HQ values of non-cancer toxic risk on humans were estimated to be in the range of $9.28 \times 10^{-12}$ to $6.56 \times 10^{-3}$. All of values were far less than 1 , suggesting that exposure to $\mathrm{PM}_{2.5}$-bound OCPs would not lead to significant adverse health effects for general population.

Table 3. Introduction of each parameter.

\begin{tabular}{llll}
\hline Logogram & Parameters & Unit & Moderate dose \\
\hline EF & Exposure frequency & days year & 365 \\
ED & Exposure duration & years & 70 \\
AT & Average time & days & $70 \times 365$ \\
InhR & Inhalation rate & $\mathrm{m}^{3} \mathrm{day}^{-1}$ & 20 \\
SA & Dermal exposure area & $\mathrm{cm}^{2}$ & 3300 \\
AF & Dermal adherence factor & $\mathrm{mg} \mathrm{cm}^{-2} \mathrm{day}^{-1}$ & 0.2 \\
ABS & Dermal adsorption fraction & - & 0.1 \\
PEF & Particle emission factor & $\mathrm{m}^{3} \mathrm{~kg}^{-1}$ & $1.36 \times 10^{9}$ \\
BW & Standard body weights & $\mathrm{kg}^{-1}$ & 61.5 \\
\hline
\end{tabular}


Table 4. Health hazard quotient (HQ) of OCPs compounds through inhale and dermal, respectively.

\begin{tabular}{lll}
\hline Compounds & HQ (inhale) & HQ (dermal) \\
\hline$\alpha-H C H$ & $9.28 \times 10^{-12}$ & $4.17 \times 10^{-5}$ \\
$\beta$-HCH & $7.45 \times 10^{-11}$ & $3.34 \times 10^{-4}$ \\
$\gamma$-HCH & $1.11 \times 10^{-10}$ & $4.97 \times 10^{-4}$ \\
p,p'-DDT & $6.12 \times 10^{-11}$ & $2.75 \times 10^{-4}$ \\
Heptachlor & $4.21 \times 10^{-11}$ & $1.89 \times 10^{-4}$ \\
Heptachlor epoxide & $1.46 \times 10^{-9}$ & $6.56 \times 10^{-3}$ \\
Aldrin & $9.05 \times 10^{-10}$ & $4.06 \times 10^{-3}$ \\
\hline
\end{tabular}

\section{ACKNOWLEDGMENTS}

Financial supports were provided by National Natural Science Foundation of China (41601548, 81602827, 21806158), Tianjin Municipal Education Commission Research Project (2017KJ244), Fundamental Research Funds of National Institute of Metrology China (AKY1720), Tianjin 131 innovative talent training project, Natural Science Foundation of Chongqing (cstc2018jcyjAX0776), Research Start-up Funding Project of Chongqing Technology and Business University (1756003) and Tianjin Special Commissioner Project (17JCTPJC53100).

\section{REFERENCES}

Batterman, S.A., Chernyak, S.M., Gounden, Y., Matooane, M. and Naidoo, R.N. (2008). Organochlorine pesticides in ambient air in Durban, South Africa. Sci. Total Environ. 397: 119-130.

Becker, S., Halsall, C.J., Tych, W., Kallenborn, R., Schlabach, M. and Man, S. (2012). Changing sources and environmental factors reduce the rates of decline of organochlorine pesticides in the Arctic atmosphere. Atmos. Chem. Phys. 12: 515-540.

Bozlaker, A., Muezzinoglu, A. and Odabasi, M. (2009). Processes affecting the movement of organochlorine pesticides (OCPs) between soil and air in an industrial site in Turkey. Chemosphere 77: 1168-1176.

Bräuner, E.V., Mayer, P., Gunnarsen, L., Vorkamp, K. and Raaschou-Nielsen, O. (2011). Occurrence of organochlorine pesticides in indoor dust. J. Environ. Monitor. 13: 522-526.

Chakraborty, P., Zhang, G., Eckhardt, S., Li, J., Breivik, K., Lam, P.K., Tanabe, S. and Jones, K.C. (2013). Atmospheric polychlorinated biphenyls in Indian cities: Levels, emission sources and toxicity equivalents. Environ. Pollut. 182: 283-290.

Cheng, J.H., Hsieh, M.J. and Chen, K.S. (2016). Characteristics and source apportionment of ambient volatile organic compounds in a science park in central Taiwan. Aerosol Air Qual. Res. 16: 221-229.

Dickhut, R.M., Cincinelli, A., Cochran, M., and Ducklow, H.W. (2005). Atmospheric concentrations and air-water flux of organochlorine pesticides along the western Antarctic Peninsula. Environ. Sci. Technol. 39: 465-470.

Han, Y., Li, X., Zhu, T., Lv, D., Chen, Y., Hou, L.a., Zhang, Y. and Ren, M. (2016). Characteristics and relationships between indoor and outdoor $\mathrm{PM}_{2.5}$ in
Beijing: A residential apartment case study. Aerosol Air Qual. Res. 16: 2386-2395.

He, J., Balasubramanian, R., Karthikeyan, S. and Joshi, U.M. (2009). Determination of semi-volatile organochlorine compounds in the atmosphere of Singapore using accelerated solvent extraction. Chemosphere 75: 640-648.

Huang, T., Guo, Q., Tian, H., Mao, X., Ding, Z., Zhang, G., Li, J., Ma, J. and Gao, H. (2014). Assessing spatial distribution, sources, and human health risk of organochlorine pesticide residues in the soils of arid and semiarid areas of northwest China. Environ. Sci. Pollut. Res. 21: 6124-6135.

Jaward, F.M., Barber, J.L., Booij, K., Dachs, J., Lohmann, R. and Jones, K.C. (2004). Evidence for dynamic air-water coupling and cycling of persistent organic pollutants over the open Atlantic Ocean. Environ. Sci. Technol. 38: 2617-2625.

Ji, T., Lin, T., Wang, F., Li, Y. and Guo, Z. (2015). Seasonal variation of organochlorine pesticides in the gaseous phase and aerosols over the East China Sea. Atmos. Environ. 109: 31-41.

Jiao, L., Lao, Q., Chen, L., Chen, F., Sun, X. and Zhao, M. (2018). Concentration and influence factors of organochlorine pesticides in atmospheric particles in a coastal island in Fujian, Southeast China. Aerosol Air Qual. Res. 18: 2982-2996.

Jin, G.Z., Kim, S.M., Lee, S.Y., Park, J.S., Kim, D.H., Lee, M.J., Sim, K.T., Kang, H.G., Kim, I.G. and Shin, S.K. (2013). Levels and potential sources of atmospheric organochlorine pesticides at Korea background sites. Atmos. Environ. 68: 333-342.

Karlsson, H., Muir, D.C.G., Teixiera, C.F., Burniston, D.A., Strachan, W.M.J., Hecky, R.E., Mwita, J., Bootsma, H.A., Grift, N.P., Kidd, K.A. and Rosenberg, B. (2000). "Persistent chlorinated pesticides in air, water, and precipitation from the Lake Malawi area, Southern Africa. Environ. Sci. Technol. 34: 4490-4495.

Kirchner, M., Jakobi, G., Körner, W., Levy, W., Moche, W., Niedermoser, B., Schaub, M., Ries, L., Weiss, P., Antritter, F., Fischer, N., Bernhard Henkelmann, B.H. and Schramm, K.W. (2016). Ambient air levels of organochlorine pesticides at three high alpine monitoring stations: Trends and dependencies on geographical origin. Aerosol Air Qual. Res. 16: 738-751.

Lammel, G., Ghim, Y., Grados, A., Gao, H., Huhnerfuss, H. and Lohmann, R. (2007). Levels of persistent organic pollutants in air in China and over the Yellow Sea. Atmos. Environ. 41: 452-464. 
Li, P., Sato, K., Hasegawa, H., Huo, M.Q., Minoura, H., Inomata, Y., Take, N., Yuba, A., Futami, M., Takahashi, T. and Kotake, Y. (2018). Chemical characteristics and source apportionment of $\mathrm{PM}_{2.5}$ and long-range transport from northeast Asia continent to Niigata in Eastern Japan. Aerosol Air Qual. Res. 18: 938-956.

Lin, T., Li, J., Xu, Y., Liu, X., Luo, C., Cheng, H., Chen, Y. and Zhang, G. (2012). Organochlorine pesticides in seawater and the surrounding atmosphere of the marginal seas of China: Spatial distribution, sources and air-water exchange. Sci. Total Environ. 435-436: 244-252.

Liu, D. (2014). Organochlorinated compounds in the air at NAEO, an eastern background site in China: LongRange atmospheric transport versus local sources. Aerosol Air Qual. Res. 14: 1258-1268.

Liu, J., Wang, Y., Li, P.H., Shou, Y.P., Li, T., Yang, M.M., Wang, L., Yue, J.J., Yi, X.L. and Guo, L.Q. (2017). Polycyclic aromatic hydrocarbons (PAHs) at high mountain site in North China: Concentration, source and health risk assessment. Aerosol Air Qual. Res. 17: 28672877.

Niu, L., Xu, C., Xu, Y., Zhang, C. and Liu, W. (2014). Hexachlorocyclohexanes in tree bark across Chinese agricultural regions: Spatial distribution and enantiomeric signatures. Environ. Sci. Technol. 48: 12031-12038.

Ozcan, S. and Aydin, M.E. (2010). Organochlorine pesticides in urban air: concentrations, sources, seasonal trends and correlation with meteorological parameters. Clean-Soil, Air, Water 37: 343-348.

Papaoikonomou, K., Emmanouil, C., Vasilato, V., Diapouli, E., Grigoratos, T., Zafirakou, A. and Kungolos, A. (2018). $\mathrm{PM}_{10}$ and elemental concentrations in a dismantling plant for waste of electrical and electronic equipment in Greece. Aerosol Air Qual. Res. 18: 1457-1469.

Qiu, X., Zhu, T., Li, J., Pan, H., Li, Q., Miao, G. and Gong, J. (2004). Organochlorine pesticides in the air around the Taihu Lake, China. Environ. Sci. Technol. 38: 1368-1374.

Rodríguez-Garrido, B., Lú-Chau, T.A., Feijoo, G., Macías, F. and Monterrroso, M.C. (2010). Reductive dechlorination of $\alpha-, \beta-, \gamma-$, and $\delta$-hexachlorocyclohexane isomers with hydroxocobalamin, in soil slurry systems. Environ. Sci. Technol. 44: 7063-7069.

Sun, J., Pan, L., Tsang, D., Zhan, Y., Zhu, L. and Li, X. (2017). Organic contamination and remediation in the agricultural soils of China: A critical review. Sci. Total Environ. 615: 724-740.

Tong, L., Zhang, J., Xu, H., Xiao, H., He, M. and Zhang, H. (2018). Contribution of regional transport to surface ozone at an island site of Eastern China. Aerosol Air Qual. Res. 18: 3009-3024.

UNEP (2003). Regionally based assessment of persistent toxic substances: Global report. United Nations.

Wang, B., Wu, C., Liu, W., Teng, Y., Luo, Y., Christie, P. and Guo, D. (2016). Levels and patterns of organochlorine pesticides in agricultural soils in an area of extensive historical cotton cultivation in Henan province, China. Environ. Sci. Pollut. Res. 23: 6680-6689.

Wang, X., Li, X., Cheng, H., Xu, X., Zhuang, G. and Zhao, C. (2008). Organochlorine pesticides in particulate matter of Beijing, China. J. Hazard. Mater. 155: 350-357.

Wang, Y., Fu, Y., Wang, C. and Wen, N. (2018). Dissimilar emission characteristics between bioaerosol and suspended particles from gaseous biofilters and bioaerosol health risk evaluation. Aerosol Air Qual. Res. 18: 1874-1885.

Wania, F., Mackay, D., Li, Y.F., Bidleman, T.F. and Strand, A. (2010). Global chemical fate of $\alpha$ hexachlorocyclohexane. 1. Evaluation of a global distribution model. Environ. Toxicol. Chem. 18: 13901399.

Widiana, D.R., Tsai, J.H., Wang, Y.F., You, S.J. and Yang, H.H. (2017). Source apportionment of air pollution and characteristics of volatile organic compounds in a municipal wastewater treatment plant, North Taiwan. Aerosol Air Qual. Res. 17: 2878-2890.

Witczak, A. and Abdelgawad, H. (2014). Assessment of health risk from organochlorine pesticides residues in high-fat spreadable foods produced in Poland. J. Environ. Sci. Health., Part B 49: 917-928.

Wurl, O., Potter, J.R., Obbard, J.P. and Durville, C. (2006). Persistent organic pollutants in the equatorial atmosphere over the open Indian Ocean. Environ. Sci. Technol. 40: 1454-1461.

$\mathrm{Xu}, \mathrm{H}$., Du, S., Cui, Z., Zhang, H., Fan, G. and Yin, Y. (2011). Size distribution and seasonal variations of particle-associated organochlorine pesticides in Jinan, China. J. Environ. Monit. 13: 2605-2611.

Yeh, C.F., Lee, C.L. and Brimblecombe, P. (2017). Effects of seasonality and transport route on chemical characteristics of $\mathrm{PM}_{2.5}$ and $\mathrm{PM}_{2.5-10}$ in the East Asian Pacific Rim Region. Aerosol Air Qual. Res. 17: 2988-3005.

Zhang, G., Li, J., Cheng, H., Li, X., Xu, W. and Jones, K.C. (2007). Distribution of organochlorine pesticides in the northern South China Sea: Implications for land outflow and air-sea exchange. Environ. Sci. Technol. 41: 3884-3890.

Zhang, L., Huang, Y., Dong, L., Shi, S., Zhou, L., Zhang, T., Mi, F., Zeng, L. and Shao, D. (2011). Levels, Seasonal Patterns, and Potential Sources of Organochlorine Pesticides in the Urban Atmosphere of Beijing, China. Arch. Environ. Contam. Toxicol. 61: 159-165.

Zhou, J., Liu, L., Xu, X., Yu, Y., Li, Y., Zhang, H. and Xu, Y. (2019). Atmospheric transport and bulk deposition of organochlorine compounds at leigongshan nature reserve in Southwestern China. Aerosol Air Qual. Res. 19: 1483-1492.

Zhou, Q., Wang, J., Meng, B., Cheng, J., Lin, G., Chen, J., Zheng, D. and Yu, Y. (2013). Distribution and sources of organochlorine pesticides in agricultural soils from central China. Ecotoxicol. Environ. Saf. 93: 163-170.

Zhou, R., Zhu, L., Yang, K. and Chen, Y. (2006). Distribution of organochlorine pesticides in surface water and sediments from Qiantang River, East China. J. Hazard. Mater. 137: 68-75.

Received for review, June 25, 2019 Revised, August 9, 2019 Accepted, August 10, 2019 